\title{
Evaluation of the Averell and Norris Method for the Determination of Parathion in West Indian Cherry (Malpighia punicifolia, L.)
}

\author{
Gilberto García Monge!
}

\section{INTRODUCTION}

The synthetic insecticide 0,0 -diethyl $O$-( $p$-nitrophenyl) thiophosphate has acquired in the United States the generic name "parathion" and the commercial name of Thiophos 3422 insecticide. Pérez $(5)^{2}$ found that this insecticide controls the fruit weevil (Anthonomus flavipes) in West Indian Cherry. As this compound is toxic to warm-blooded animals, it is necessary to obtain data on crop parathion residue as a result of parathion treatment before definite recommendations for satisfactory pest control are made. In order to obtain these residue data it was decided to evaluate the Averell and Norris (1) procedure when applied to West Indian Cherry.

\section{LITERATURE REVIEW}

Gunter and Blinn (4) mentioned that in the composition analysis of parathion, this insecticide is determined by ultraviolet spectrophotometric examination $\left(\lambda_{\max } .274 \mathrm{~m} \mu\right)$. In residue analysis the parathion must be extracted from the plant material. The parathion on the extract is mixed with other organic compounds found in plant material which will probably absorb in the ultraviolet region interfering with the absorption of parathion. It does appear that the nitro group in the parathion molecule offers the best approach to a colorimetric method. In the Averell and Norris method this nitro group is reduced to an amino group which is diazotized with sodium nitrite and coupled with N-(1-naphtyl)-ethylenediamine dihydrochloride to produce an intense magenta color $\left(\lambda_{\max } .555 \mathrm{~m} \mu\right)$.

Wilson, et al. (8), described a modification of the original method of Averell and Norris for the determination of parathion in citrus oil. The benzene extract of plant material was used without any pretreatment and the quantity of sample required was drastically reduced. Isopropyl alcohol was substituted for ethyl alcohol.

Edwards (3) analyzed benzene samples from several manufacturers following the Averell and Norris procedure. He found an apparent parathion concentration ranging from 6.8 to $68.8 \mu \mathrm{g} . / 200 \mathrm{ml}$. of benzene.

\footnotetext{
1 Research Assistant in Chemistry, Agricultural Experiment Station, University of Puerto Rico, Río Piedras, P.R.

2 Italic numbers in parentheses refer to Literature Cited, p. 53.
} 
Spectro-transmittance curves for nitrobenzene and benzene showed the absorption maximum about $555 \mathrm{~m} \mu$ which corresponds to a reduced and coupled parathion maximum. Inasmuch as c.p. benzene is the solvent recommended for stripping parathion residue from plant material, this solvent may constitute a common source of error.

Blinn and Gunther (2) made a spectral study of methyl anthranilate, a substance found in grapes. The methyl anthranilate hydrochloride was carefully purified and subjected to the exact reducing, diazotizing, and coupling procedure used for parathion estimations (1). The absorption maximum for methyl anthranilate differs by only $8 \mathrm{~m} \mu$ from the parathion maximum. It was shown that if methyl anthranilate is present in the plant material it interferes seriously in a determination for parathion by the above-mentioned procedure.

\section{MATERIALS AND METHODS}

Fresh West Indian Cherries were ground in a Waring Blendor. Twohundred-and-fifty-gram samples of the pulp were weighed in duplicate and fortified with known concentrations of parathion ranging from 0 to 2.4 p.p.m. of parathion in benzene. The samples were mixed with $500 \mathrm{gm}$. of benzene and extracted as described previously by Roldán $(6)$. Two hundred and fifty grams of the benzene extract were weighed into a $300-\mathrm{ml}$. tall-form beaker and decolorized with $11 \mathrm{gm}$. of a mixture of Attapulgus Clay and Hyflo Super-cel, using a batch method rather than the column method described by Averell and Norris. The clay-Hyflo Super-cel mixture was never allowed to dry during the process of filtration and washing with benzene.

The decolorized benzene solution was concentrated to $10 \mathrm{ml}$. in a $300-\mathrm{ml}$. tall-form beaker on a steam bath. The last $10 \mathrm{ml}$. of benzene were removed at room temperature by passing air over the surface, evaporation being discontinued as soon as the residue was dry. This residue was dissolved and the color developed as described by Averell and Norris (1). The spectro-transmittance curve determined in a Coleman Universal Spectrophotometer, Model 14, showed an absorption maximum at about $555 \mathrm{~m} \mu$. The standard transmission-concentration curve was prepared by using a stock solution of parathion in benzene. A blank solution, consisting of $10 \mathrm{ml}$. of benzene with no parathion, was used to set the spectrophotometer scale at 100-percent transmittance. A straight-line relationship was obtained by plotting milligrams of parathion against percentage transmittance. The same kind of relationship was obtained by Averell and Norris (1) as well as by Santini and Sotelo (7).

Under the experimental conditions adopted in these systems the meas- 
ured concentrations in the Coleman Spectrophotometer are believed to be reliable in 0.1 p.p.m.

\section{RESULTS AND DISCUSSION}

Table 1 presents the results obtained by the Averell and Norris procedure in the recovery of parathion from West Indian Cherry. The corrected parathion concentrations were obtained after subtracting the apparent parathion concentration of benzene from each sample. Edwards (3) recommended a distillation for removal of interfering substances found in benzene. This procedure is more expensive, time-consuming, and hazardous that the above-mentioned procedure under the experimental conditions adopted in these systems.

TABLE 1.-Recovery of parathion from fortified West Indian Cherry

\begin{tabular}{c|c|c|c|c}
\hline Sample No. & Parathion Added & $\begin{array}{c}\text { Apparent Parathion } \\
\text { Concentration }\end{array}$ & $\begin{array}{c}\text { Corrected Parathion } \\
\text { Concentration }\end{array}$ & Recovery \\
\cline { 2 - 4 } 1 & $P . p . m$. & $P . p . m$. & $P . p . m$. & Percent \\
\cline { 2 - 3 } 2 & 0.2 & 0.46 & 0.18 & 88 \\
3 & .4 & .62 & .34 & 8 \\
4 & .8 & .96 & .68 & 85 \\
5 & 1.0 & 1.18 & .90 & 90 \\
6 & 1.4 & 1.48 & 1.20 & 86 \\
71 & 2.4 & 2.03 & 1.75 & 73 \\
$8^{2}$ & 0 & .26 & - & - \\
\hline
\end{tabular}

${ }^{1}$ West Indian Cherry without fortification.

2 Solvent alone (benzene).

From table 1 the following conclusions can be made:

1. Satisfactory recovery of parathion was obtained from the West Indian Cherry. The average recovery was 85 percent.

2. Benzene used as a solvent in the Averell and Norris (1) procedure for the determination of parathion developed a magenta color which absorbs in the same spectral region of the color developed by parathion. This was previously observed by Edwards (3) and explained as being due to nitro or amine aromatic groups present as impurities in benzene. During the procedure the benzene extract is concentrated 25 times causing also a concentration of the impurities.

3. West Indian Cherries contain no interference background when analyzed by the Averell and Norris procedure for parathion. Therefore, the Averell and Norris method can be employed satisfactorily for the analysis of parathion residue in West Indian Cherry. 


\section{SUMMARY}

This paper presents the results obtained in studies carried out in the evaluation of the Averell and Norris procedure for parathion determinations as applied to the West Indian Cherry. The data obtained showed that the samples need to be corrected for the interference effect of the solvent, benzene, which contains an appreciable apparent concentration of parathion. West Indian Cherries offer no interference background to the above procedure. Therefore, satisfactory residue data can be obtained for the West Indian Cherry by the Averell and Norris method.

\section{RESUMEN}

Se presentan los resultados obtenidos en estudios hechos en la evaluación del método de Averell y Norris en acerola. Los resultados demuestran que las muestras tienen que corregirse para una interferencia en el solvente, el cual contiene una cantidad aparente de paración. La acerola no contiene niguna substancia que interfiera en el método descrito.

Por lo tanto, se pueden obtener resultados satisfactorios para residuos de paración en acerola usando el método de Averell y Norris.

\section{LITERATURE CITED}

1. Averell, P. R., and Norris, M. V., Estimation of small amounts of O,O-Diethy] O-( $p$-Nitrophenyl) Thiophosphate, Anal. Chem. 20 753-6, 1948.

2. Blinn, R. C., and Gunther, F. A., Interference of methyl anthranilate in estimation of parathion, Anal. Chem. $221219,1950$.

3. Edwards, F. I., Jr., Source of error in estimating small amounts of parathion. Anal. Chem. 21 1415, 1949.

4. Gunther, F. A., and Blinn, R. C., Analysis of Insecticides and Acaricides, Interscience Publishers, Inc., pp. 505-7, New York, N.Y., 1955.

5. Pérez, M., Department of Entomology, Agricultural Experiment Station of the University of Puerto Rico, personal communication.

6. Roldán, J., Parathion residue studies on acerola, J. Agr. Univ. P.R. 43 147-51, 1959.

7. Santini, Jr., R., and Sotelo, E., Determination of 0,0 -diethyl O-p-nitrophenyl thiosphosphate (parathion) in pineapples, J. Agri. Univ. P.R., 39(1) 12-5, 1955.

8. Wilson, C. W., Barer, Rodger, Genung, Dale, and Mullow, James, Estimation. of O,O-diethyl O-(p-nitrophenyl) thiosphosphate, Anal. Chem. 23 1487-9, 1951. 